\title{
Laboratory dilutions of thioridaxine with potential to enhance antibiotic sensitivity in a multidrug resistant Escherichia coli uropathogen
}

\author{
Otajevwo F. D., Iyabor F. O. \\ Dept. of Microbiology \& Biotechnology, Western Delta University, Oghara, Nigeria
}

Email address:

fesdotaj@yahoo.com (Otajevwo F. D.), dafotaj@hotmail.com (Otajevwo F. D.)

To cite this article:

Otajevwo F. D., Iyabor F. O.. Laboratory Dilutions of Thioridaxine with Potential to Enhance Antibiotic Sensitivity in a Multidrug Resistant Escherichia Coli Uropathogen. Science Journal of Clinical Medicine. Vol. 4, No. 2, 2015, pp. 32-40. doi: 10.11648/j.sjcm.20150402.13

\begin{abstract}
This research effort seeks to use doses of thioridaxine to enhance antibiotic sensitivity in a MDR Escherichia coli strain. Five axenic (pure) strains of Escherichia coli coded $\mathrm{EC}_{1}$ to $\mathrm{EC}_{5}$ were obtained from five infected midstream urine samples among several other urine samples inoculated on sterile Cystine Lactose Electrolyte Deficient (CLED) agar with appropriate labeling in the Microbiology and Biotechnology Laboratory of Western Delta University, Oghara, Nigeria and stocked on sterile Nutrient agar slants at $4^{\circ} \mathrm{C}$ in a refrigerator. Slant cultures were sub-cultured aseptically on fresh sterile CLED agar plates and incubated aerobically at $37^{\circ} \mathrm{C}$ for $24 \mathrm{hrs}$ to confirm Escherichia coli strains. Gram staining, indole production, methyl red test, voges praskaeur and citrate utilization tests were done on the resulting colonies to further confirm the strains as E.coli. Antibiotic susceptibility test was done by agar disc diffusion method on all confirmed strains on sterile Mueller- Hinton agar plates before and after treatment with laboratory dilutions of thioridaxine. Only E.coli strain $2\left(\mathrm{EC}_{2}\right)$ was multidrug resistant as it resisted $4(44.4 \%)$ of the antibiotics used which were cefuroxime, nalidixic acid, augmentin and tetracycline. Other strains resisted $1-2$ antibiotics. The highest $(15.6 \pm 20.6 \mathrm{~mm})$ and least $(2.0 \pm 8.1 \mathrm{~mm})$ zones of inhibition by all five strains were recorded for ofloxacin and cefuroxime respectively. Whereas all five uropathogen strains resisted augmentin, they were sensitive to ciprofloxacin, ofloxacin (both being fluoroquinolones), gentamicin, chloramphenicol and nitrofurantoin. After treatment with $2000-2240 \mathrm{ug} / \mathrm{ml}$ laboratory dilutions of thioridaxine, $\leq 50.0 \%$ loss of resistance was recorded for $2040 \mathrm{ug} / \mathrm{ml}, 2160 \mathrm{ug} / \mathrm{ml}$ and $2240 \mathrm{ug} / \mathrm{ml}$ dilutions. Thioridaxine dilution of $2040 \mathrm{ug} / \mathrm{ml}$ induced $250 \%$ and $90 \%$ resistance losses of $\mathrm{EC}_{2}$ to ciprofloxacin and nitrofurantoin respectively with an overall mean \pm S.E loss of $68.0 \pm 24.4 \%$. Resistance losses of $112.5 \%, 130.0 \%$ and $100.0 \%$ to ciprofloxacin, nitrofurantoin and chloramphenicol respectively were recorded after $2160 \mathrm{ug} / \mathrm{ml}$ treatment and $68.5 \pm 16.3 \%$ overall loss of resistance. Thioridaxine dilutions of $2240 \mathrm{ug} / \mathrm{ml}$ induced $55.6 \pm 25.0 \%$ overall loss of resistance with a corresponding $50.0 \%, 50.0 \%, 58.1 \%, 70.0 \%$ and $50.0 \%$ resistance losses with gentamicin, ciprofloxacin, ofloxacin, nitrofurantoin and chloramphenicol respectively. Less than 50\% resistance losses were recorded for 2000, 2080, 2120 and $2200 \mathrm{ug} / \mathrm{ml}$ dilutions. Minimum inhibitory concentration of chloramphenicol was lowered by $2080 \mathrm{ug} / \mathrm{ml}, 2160 \mathrm{ug} / \mathrm{ml}$ and $2240 \mathrm{ug} / \mathrm{ml}$ dilutions by two-fold (15ug), two-fold (15ug) and four-fold (7.5ug) respectively. The medical/ chemotherapeutic implications of these findings are discussed.
\end{abstract}

Keywords: Invitro, Dilutions, Thioridaxine, Enhance, Antibiotic, Sensitivity, MDR E.coli

\section{Introduction}

Antibiotics resistance is not a new phenomenon. However, the current magnitude and speed with which it is developing is a cause for global concern (Namita et al., 2012). According to WHO (2012), antimicrobial resistance is on the rise in Europe and all over the world with gradual loss of first line antimicrobials. Epidemiological studies have suggested that antibiotic resistance genes emerge in microbial populations within 5 years of the therapeutic introduction of an antibiotic (Chakrabarty et al., 1990).

Hence, numerous classes of antimicrobial agents have become less effective as a result of the emergence of antimicrobial resistance often as a result of the selective pressure of their daily usage (Osakay et al., 2009). This selective pressure can be attributed to indiscriminate use of antibiotics, complex socio- economic behavioural antecedents and dissemination of drug resistant pathogens in 
human medicine (Okeke et al., 1999). Moreover, the disappointing lack of new antimicrobial agents has led to overuse of existing ones thus leading to the emergence of multi-resistant pathogens (McGowan, 2006).

Therefore, as the proliferation of multidrug resistant pathogens continue unavoidably within and around us, it is important that their resistance trend be put under check through intensive research and antibiotic surveillance (Akortha and Filgona, 2009). The primary causes of antibiotic resistance in bacteria are mobile elements called plasmids and conjugative transposons. Plasmids are extra chromosomal DNA elements that have the capacity to replicate independently of the chromosome of the bacterial cell (Madigan et al., 2003). Resistance plasmids or $\mathrm{R}$ plasmids code for enzymes that can inactivate antibiotics, prevent the uptake of an antibiotic or pump out the particular antibiotic (Neu, 1989). Other causes of antibiotic resistance are efflux pumps, mutation, under dosage or use of drugs without prescription (Amaral et al., 2013). Plasmids carry genes some of which code for beta-lactamase or extended spectrum beta lactamases which can inactivate or degrade drugs thus rendering them ineffective (Amaral et al., 2013).

Curing is the process of removing plasmids from a bacterial cell (Trevors, 1986). The resulting bacterial organism then becomes sensitive to the selective agent and it was initially thought that this phenomenon would proffer solution in controlling the development of antibiotic resistance in formerly antibiotic susceptible bacteria. Novobiocin, ethidium bromide, acriflavine, acridine orange, ascorbic acid and elevated temperatures have been used as curing agents (Ramesh et al., 2000). Physical treatments, chemical compounds and growth conditions may increase the frequency of elimination of drug resistant R-plasmids, resulting in sensitive cells that were previously resistant to antibiotics (Lakshmi et al., 1981). DNA intercalating dyes (ethidium bromide), sodium dodecyl sulphate (SDS), antibiotics, thymine starvation and elevated temperatures have been used as curing agents (Chakrabarrty et al., 1984; Gupta et al., 1980; Obaseki-Ebor, 1984; Reddy et al., 1986).

It has been reported that phenothiazines have the ability to control overexpression of efflux pump systems and thus are able to remove or reduce antibiotic resistance (Viveiros et al., 2010; Amaral et al., 2013). Mukherjee et al. (2012) reported the use of $1000-3000 \mathrm{ug} / \mathrm{ml}$ dilutions of a type of phenothiazine and an anti-psychotic drug called thioridaxine to cure a multidrug resistant strain of Pseudomonas aeruginosa.

Multidrug resistance is now common among familiar pathogens such as Escherichia coli, Staphylococcus aureus, Klebsiella pneumoniae, etc. Escherichia coli causes about $85 \%$ of community acquired UTIs, $50 \%$ of hospital acquired (nosocomial) UTIs and more than $80 \%$ cases of uncomplicated pyelonephritis (Bergeron, 1995). The antibiotic sensitivities of different strains of E.coli vary widely. As a gram negative organism, E.coli is resistant to many antibiotics that are effective against gram positive organisms (Johnson et al., 2006). E.coli bacteria often carry multidrug resistance plasmids and under stress, readily transfer those plasmids to other species (Salyers et al., 2004).

Extended spectrum beta-lactamase producing E.coli are highly resistant to an array of antibiotics and infections by these strains of E.coli are highly difficult to treat (Paterson and Bonomo, 2005). Virulent strains of E.coli can cause infantile gastro-enteritis, pelvic inflammatory disease and neonatal meningitis (Todar, 2007).

Treatments that increase frequency of elimination of plasmids will certainly enhance sensitivity (effectiveness) of antibiotics in situ. There is no published current work on use of laboratory dilutions of thioridaxine in the treatment (curing) of a multidrug resistant Escherichia coli uropathogen. The focus of this work therefore, is the use of laboratory dilutions of thioridaxine to enhance the antibiotic sensitivity of a multidrug resistant Escherichia coli uropathogen with the following objectives:

1 Determine the antibiograms of five selected Escherichia coli pure culture strains obtained from cultures of midstream urine samples after $37^{\circ} \mathrm{C}$ incubation for $24 \mathrm{hrs}$ with the aim of selecting a multiantibiotic resistant strain.

2 Determine the antibiotic susceptibility profiles of a selected MDR E.coli strain in terms of $\leq 50 \%$ resistance loss after treatment with laboratory dilutions of thioridaxine (i.e. $2000-2240 \mathrm{ug} / \mathrm{ml}$ ).

3 Show a summary of data of $\leq 50 \%$ resistance loss by thioridaxine dilutions after treatment on the MDR E.coli strain.

4 Determine thioridaxine dilutions' effect(s) on the minimum inhibitory concentration (MIC) of a selected antibiotic that recorded borderline loss of resistance (i.e. between $45-49 \%$ as borderline to $\leq 50 \%$ ).

\section{Materials and Methods}

\subsection{Sampling}

Five pure (axenic) isolates (strains) of Escherichia coli were obtained from $24 \mathrm{hr}$ Cystine lactose Electrolyte Deficient (CLED) agar plate cultures. The agar plate medium used was one of several agar plates which had been inoculated with freshly voided midstream urine samples by a graduating student working on urinary tract infection in the Microbiology and Biotechnology laboratory of Western Delta University, Oghara.

The status of the E.coli isolates (strains) was re-confirmed by gram reaction, biochemical and sugar fermentation tests by standard methods (Cowan and Steel, 1993). After confirmation, all gram negative, raised, entire, circular, motile, indole positive, methyl red positive, voges praskauer negative, citrate negative, urease negative, lactose and glucose fermenting colonies were stocked (i.e. streaked aseptically) on sterile nutrient agar ( LabM, UK) slants and incubated at $37^{\circ} \mathrm{C}$ for $24 \mathrm{hrs}$. The resulting cultures were kept at $4^{\circ} \mathrm{C}$ in the refrigerator for further use after appropriate labeling. The five bacterial uropathogens were then subjected 
to antibiotic sensitivity testing before treatment with laboratory dilutions of thioridaxine.

\subsection{Antibiotic Sensitivity Testing}

The five stocked E.coli strains were first subcultured on sterile CLED agar medium and incubated at $37^{\circ} \mathrm{C}$ for 24hours. Antibiotic sensitivity testing was then carried out on the resulting pure culture colonies using the agar disc diffusion method on sterile Mueller-Hinton agar (MHA) plates (Bauer et al., 1966). A loopful of each colony of the uropathogens was picked aseptically using a flamed and cooled wire loop and placed in the centre of the sterile MHA plates. This was then spread all over the plates applying the caution of not touching the edges of the plates. The seeded plates were allowed to stand for about 2 minutes to allow the agar surface to dry. A pair of forceps was flamed and cooled and used to pick an antibiotic multidisc (Abitek, Liverpool) containing augmentin (30ug), ofloxacin (5ug), gentamicin (10ug), nalidixic acid (30ug), nitrofurantoin (200ug), tetracycline (25ug), chloramphenicol (30ug), ciprofloxacin (10ug) and cefuroxime (30ug). The discs were placed at least $22.0 \mathrm{~mm}$ from each other and $14.0 \mathrm{~mm}$ from the edge of the plates (Ochei and Kolkhatkar, 2008). Antibiotic discs were selected on the basis of their clinical importance and efficacy on various pathogenic strains of Escherichia coli. The seeded plates were allowed to stand for $10 \mathrm{mins}$ before incubation (Mbata, 2007).

At the end of incubation, the diameters of the zones of inhibition from one edge to the opposite were measured to the nearest millimeter using a transparent ruler (Byron et al., 2003). Strains that showed resistance against three antibiotics and above were termed multiple drug resistant strains (Jan et $a l ., 2004)$ and were noted and used further.

\subsection{Preparation of Laboratory Dilutions of Thioridaxine}

Thioridaxine, a phenothiazine (also known as 2Methylmercapto-10-(2-N-methyl-2-piperidyl-ethyl

phenothiazine) dilutions of $2000-2240 \mathrm{ug} / \mathrm{ml}$ were chosen based on the lethal Dose-50 $\left(\mathrm{LD}_{50}\right)$ of $956-1034 \mathrm{mg} / \mathrm{kg}$ administered orally on rats as reported by Barth et al. (2006) and in line with a similar study carried out by Mukherjee et al. (2011). Laboratory thioridaxine dilutions of $2000 \mathrm{ug} / \mathrm{ml}$, $2040 \mathrm{ug} / \mathrm{ml}, 2080 \mathrm{ug} / \mathrm{ml}, 2120 \mathrm{ug} / \mathrm{ml}, 2160 \mathrm{ug} / \mathrm{ml}, 2200 \mathrm{ug} / \mathrm{ml}$ and $2240 \mathrm{ug} / \mathrm{ml}$ were therefore prepared using $\mathrm{RV} / \mathrm{O}$ where stock or original concentration of thioridaxine used was 50mg tablet (Southwood Pharmaceuticals, UK). The 50mg tablet was originally dissolved in $10 \mathrm{ml}$ sterile water to give $5 \mathrm{mg} / \mathrm{ml}$ which is equivalent to $5000 \mathrm{ug} / \mathrm{ml}$. To obtain $2000 \mathrm{ug} / \mathrm{ml}$ dilution, $2 \mathrm{ml}$ of stock or original drug $(5000 \mathrm{ug} / \mathrm{ml}$ thioridaxine) was mixed or diluted with $3 \mathrm{ml}$ sterile water.

To obtain $2040 \mathrm{ug} / \mathrm{ml}$ dilution, $5.1 \mathrm{ml}$ of stock was mixed with $7.4 \mathrm{ml}$ of sterile water. A mixture of $5.2 \mathrm{ml}$ of stock drug solution with $7.3 \mathrm{ml}$ of sterile diluent resulted in a dilution of $2080 \mathrm{ug} / \mathrm{ml}$ and $2120 \mathrm{ug} / \mathrm{ml}$ dilution was obtained by mixing $5.3 \mathrm{ml}$ of original drug solution with $7.2 \mathrm{ml}$ of diluent (sterile water). To obtain $2160 \mathrm{ug} / \mathrm{ml}$ dilution, $5.4 \mathrm{ml}$ stock drug solution was mixed with $7.1 \mathrm{ml}$ of diluent, while a mixture of $1.1 \mathrm{ml}$ of stock with $1.4 \mathrm{ml}$ of diluent gave a dilution of $2200 \mathrm{ug} / \mathrm{ml}$. Lastly, $2240 \mathrm{ug} / \mathrm{ml}$ was obtained by mixing $5.6 \mathrm{ml}$ of stock with $6.9 \mathrm{ml}$ of diluent.

\subsection{Growing Broth Culture of MDR Escherichia coli Strain $2\left(E C_{2}\right)$}

The stock culture of $\mathrm{EC}_{2}$ was selected from among the initial five stocked strains. An inoculum of $\mathrm{EC}_{2}$ was aseptically picked from its slant stock culture using flamed and cooled wire loop and inoculated into $10 \mathrm{ml}$ sterile Nutrient broth (LabM, UK). The inoculated broth was incubated at $37^{\circ} \mathrm{C}$ for $18 \mathrm{hrs}$. The resulting turbid broth culture was then diluted according to a modified method of Shirtliff et al. (2006). Using a sterile pipette, $0.1 \mathrm{ml}$ of broth culture was mixed with $19.9 \mathrm{ml}$ (1:200 dilution) of sterile Nutrient broth. This was properly mixed and was used as working inoculum and should contain $10^{5}$ to $10^{6}$ organisms and used within 30 minutes (Ochei and Kolhatkar, 2008).

\subsection{Treatment of $\mathrm{EC}_{2}$ Uropathogen with Prepared Thioridaxine Dilutions}

The treatment of MDR Escherichia coli strain 2 with the prepared thioridaxine dilutions was done according to a modified method by Byron et al. (2003). Using a sterile pasteur pipette, $0.5 \mathrm{ml}$ aliquot of the diluted overnight broth culture of $\mathrm{EC}_{2}$ uropathogen was added to $4.5 \mathrm{ml}$ sterile molten Nutrient agar (LabM, UK) and mixed. The various prepared dilutions (one at a time) of thioridaxine were then added in $0.5 \mathrm{ml}$ volume. The set up for each dilution was then poured on top of sterile hardened or set $2 \%$ Nutrient agar plates and left to set. The same antibiotic multidiscs used before treatment were then picked (using flamed and cooled pair of forceps) and impregnated on the set agar overlay plates. Plates were incubated at $37^{\circ} \mathrm{C}$ for $24 \mathrm{hrs}$. Measurement of diameter of zones of inhibition was taken and recorded (NCCLS, 2000).

\subsection{Determination of Effect of Thioridaxine Dilutions Treatment on MIC of Chloramphenicol}

Serial doubling dilutions of chloramphenicol (using its MIC of 30ug as a basis) was carried out. Chloramphenicol was chosen for this assay because it showed a mean $\pm \mathrm{S}$.E resistance loss of $45.0 \pm 20.0$ across all the dilutions and $45 \%$ is a borderline of $\leq 50.0 \%$ which is the benchmark for the purpose of this study. The idea is that any thioridaxine dilution that can reduce the MIC may enhance its sensitivity and therefore, loss of resistance is likely to shore up from $45 \%$. Sterile cotton wool plugged test tubes numbering 11 (eleven) were set up on a test tube rack and labeled 1-11. Using a sterile pipette, $1 \mathrm{ml}$ of sterile nutrient broth was dispensed into tubes 2 to 7 . Two milliliters of Nutrient broth was dispensed into tube 8 as Nutrient broth control. Tubes 27 were then labeled with chloramphenicol concentrations of $120 \mathrm{ug} / \mathrm{ml}, 60 \mathrm{ug} / \mathrm{ml}, 30 \mathrm{ug} / \mathrm{ml}, 15 \mathrm{ug} / \mathrm{ml}, 7.5 \mathrm{ug} / \mathrm{ml}, 3.75 \mathrm{ug} / \mathrm{ml}$ and $1.88 \mathrm{ug} / \mathrm{ml}$. A $250 \mathrm{mg}$ capsule of chloramphenicol was 
dissolved in $10 \mathrm{ml}$ of sterile water and diluted to $240 \mathrm{ug} / \mathrm{ml}$ using $\mathrm{RV} / \mathrm{O}$ in a sterile $200 \mathrm{ml}$ transparent bottle. From this $240 \mathrm{ug} / \mathrm{ml}$ chloramphenicol preparation, $2 \mathrm{ml}$ volume was pipetted into tube 1 . From tube 1, one milliliter was pipetted into tube 2 and mixed and $1.0 \mathrm{ml}$ was pipetted into tube 3 and mixed. From tube $3,1.0 \mathrm{ml}$ was pipetted into tube 4 . Finally, $1.0 \mathrm{ml}$ was pipetted into tube 7 , mixed and $1.0 \mathrm{ml}$ was pipetted out and discarded. The diluted E.coli inoculum was then dispensed in $0.5 \mathrm{ml}$ volume into tubes 2 to 7 . Into tube 10 , two milliliters of the diluted broth culture was dispensed as inoculum control. Into tube 9 , two milliliters of the $240 \mathrm{ug} / \mathrm{ml}$ chloramphenicol diluted drug was dispensed as drug control. The first dilution of thioridaxine $(2000 \mathrm{ug} / \mathrm{ml})$ was then added (in $0.5 \mathrm{ml}$ volume) to each tube and the content of each tube was properly mixed. The set up was repeated for each of the other dilutions of thioridaxine.

All tubes were incubated in a water bath at $37^{\circ} \mathrm{C}$ for $24 \mathrm{hrs}$. The MICs as affected by each thioridaxine dilution were read and recorded.

\section{Results}

Table 1 shows antibiograms of Escherichia coli strains 1-5 isolated from mid-stream urine samples of which their sensitivity responses to cefuroxime, nalidixic acid, gentamicin, ciprofloxacin, tetracycline, chloramphenicol, ofloxacin, augmentin and nitrofurantoin are shown. E.coli strains 1 and 4 resisted two antibiotics each (cefuroxime and augmentin) while $\mathrm{EC}_{3}$ and $\mathrm{EC}_{5}$ each resisted one antibiotic which incidentally was augmentin. Only E.coli strain 2 resisted three antibiotics and these were cefuroxime, nalidixic acid and augmentin.

The highest $(15.6 \pm 20.1 \mathrm{~mm})$ and least $(2.0 \pm 8.1 \mathrm{~mm})$ zones of inhibition by all five strains were recorded for ofloxacin and cefuroxime respectively. All the five E.coli uropathogens resisted augmentin.

Because E.coli strain 2 resisted three antibiotics, it was considered a multidrug resistant uropathogen and was used further in the study.

Table 1. Sensitivity Profile of five Escherichia coli strains before treatment with laboratory dilutions of thioridaxine after incubation at $37^{\circ} \mathrm{C}$ for $24 \mathrm{hrs}$.

\begin{tabular}{lccccccccc}
\hline \multirow{2}{*}{ Strain Code } & \multicolumn{10}{c}{ Zones of inhibition (mm) } \\
\cline { 2 - 11 } & CRX & NAL & GEN & CPR & TET & CHL & OFL & AUG & NIT \\
\hline $\mathrm{EC}_{1}$ & 0.0 & 7.0 & 15.0 & 10.0 & 5.0 & 6.0 & 15.0 & 0.0 & 9.0 \\
$\mathrm{EC}_{2}$ & 0.0 & 0.0 & 12.0 & 8.0 & 0.0 & 6.0 & 24.0 & 0.0 & 10.0 \\
$\mathrm{EC}_{3}$ & 4.0 & 5.0 & 7.0 & 12.0 & 4.0 & 8.0 & 11.0 & 0.0 & 9.0 \\
$\mathrm{EC}_{4}$ & 0.0 & 10.0 & 13.0 & 15.0 & 8.0 & 10.0 & 16.0 & 0.0 & 12.0 \\
$\mathrm{EC}_{5}$ & 6.0 & 12.0 & 6.0 & 6.0 & 7.0 & 11.0 & 12.0 & 0.0 & 8.0 \\
$\mathrm{Mean} \pm$ S.E & $2.0 \pm 8.1$ & $6.8 \pm 11.2$ & $10.6 \pm 7.2$ & $10.2 \pm 8.1$ & $4.8 \pm 6.1$ & $8.2 \pm 5.6$ & $15.6 \pm 20.1$ & 0.0 & $9.6 \pm 11.3$ \\
\hline
\end{tabular}

$\mathrm{CRX}=$ Cefuroxime, $\mathrm{NAL}=$ Nalidixic $\mathrm{Acid}, \mathrm{GEN}=$ Gentamicin, $\mathrm{CPR}=$ Ciprofloxacin, $\mathrm{TET}=$ Tetracycline, $\mathrm{CHL}=\mathrm{Chloramphenicol}$

$\mathrm{OFL}=$ Ofloxacin, $\mathrm{AUG}=$ Augmentin, $\mathrm{NIT}=$ Nitrofurantoin, $\mathrm{EC}_{1}-\mathrm{EC}_{5}=$ Escherichia coli strains 1-5.

Table 2. Thioridaxine dilutions that induced $\leq 50.0 \%$ loss in resistance after treatment on a multidrug resistant Escherichia coli uropathogen.

\begin{tabular}{|c|c|c|c|c|c|c|c|c|c|}
\hline \multirow{2}{*}{$\begin{array}{l}\text { Thioridaxine lab } \\
\text { dilutions }\end{array}$} & \multicolumn{9}{|c|}{ Selected Antibiotics (\% improvements in sensitivity) } \\
\hline & Treatments & NAL & GEN & CPR & TET & CHL & OFL & AUG & NIT \\
\hline \multirow[b]{2}{*}{$2000 \mathrm{ug} / \mathrm{ml}$} & Before & 0.0 & 12.0 & 8.0 & 0.0 & 6.0 & 24.0 & 0.0 & 10.0 \\
\hline & After & $\begin{array}{c}0.0 \\
(0.0)\end{array}$ & $\begin{array}{c}14.0 \\
(16.7)\end{array}$ & $\begin{array}{c}10.0 \\
(25.0)\end{array}$ & $\begin{array}{c}0.0 \\
(0.0)\end{array}$ & $\begin{array}{c}13.0 \\
(115.0)\end{array}$ & $\begin{array}{l}25.0 \\
(4.2)\end{array}$ & $\begin{array}{c}0.0 \\
(0.0)\end{array}$ & $\begin{array}{c}19.0 \\
(90.0)\end{array}$ \\
\hline \multirow[b]{2}{*}{$2040 \mathrm{ug} / \mathrm{ml}$} & Before & 0.0 & 12.0 & 8.0 & 0.0 & 6.0 & 24.0 & 0.0 & 10.0 \\
\hline & After & $\begin{array}{c}0.0 \\
(0.0)\end{array}$ & $\begin{array}{c}16.0 \\
(33.3)\end{array}$ & $\begin{array}{c}28.0 \\
(250.0)\end{array}$ & $\begin{array}{c}0.0 \\
(0.0)\end{array}$ & $\begin{array}{c}6.0 \\
(0.0)\end{array}$ & $\begin{array}{c}28.0 \\
(16.7)\end{array}$ & $\begin{array}{c}0.0 \\
(0.0)\end{array}$ & $\begin{array}{c}19.0 \\
(90.0)\end{array}$ \\
\hline \multirow[b]{2}{*}{$2080 \mathrm{ug} / \mathrm{ml}$} & Before & 0.0 & 12.0 & 8.0 & 0.0 & 6.0 & 24.0 & 0.0 & 10.0 \\
\hline & After & $\begin{array}{c}0.0 \\
(0.0)\end{array}$ & $\begin{array}{c}18.0 \\
(50.0)\end{array}$ & $\begin{array}{c}16.0 \\
(50.0)\end{array}$ & $\begin{array}{c}0.0 \\
(0.0)\end{array}$ & $\begin{array}{c}9.0 \\
(50.0)\end{array}$ & $\begin{array}{c}27.0 \\
(12.5)\end{array}$ & $\begin{array}{c}0.0 \\
(0.0)\end{array}$ & $\begin{array}{c}15.0 \\
(50.0)\end{array}$ \\
\hline \multirow[b]{2}{*}{$2120 \mathrm{ug} / \mathrm{ml}$} & Before & 0.0 & 12.0 & 8.0 & 0.0 & 0.0 & 24.0 & 0.0 & 10.0 \\
\hline & After & $\begin{array}{c}0.0 \\
(0.0)\end{array}$ & $\begin{array}{l}12.0 \\
(0.0)\end{array}$ & $\begin{array}{c}14.0 \\
(75.0)\end{array}$ & $\begin{array}{c}0.0 \\
(0.0)\end{array}$ & $\begin{array}{c}0.0 \\
(0.0)\end{array}$ & $\begin{array}{c}36.0 \\
(50.0)\end{array}$ & $\begin{array}{c}0.0 \\
(0.0)\end{array}$ & $\begin{array}{c}18.0 \\
(18.0)\end{array}$ \\
\hline \multirow[b]{2}{*}{$2160 \mathrm{ug} / \mathrm{ml}$} & Before & 0.0 & 12.0 & 8.0 & 0.0 & 6.0 & 24.0 & 0.0 & 10.0 \\
\hline & After & $\begin{array}{c}0.0 \\
(0.0)\end{array}$ & $\begin{array}{l}12.0 \\
(0.0)\end{array}$ & $\begin{array}{c}17.0 \\
(112.5)\end{array}$ & $\begin{array}{c}0.0 \\
(0.0)\end{array}$ & $\begin{array}{c}12.0 \\
(100.0)\end{array}$ & $\begin{array}{c}27.0 \\
(12.5)\end{array}$ & $\begin{array}{c}0.0 \\
(0.0)\end{array}$ & $\begin{array}{c}23.0 \\
(130.0)\end{array}$ \\
\hline \multirow[b]{2}{*}{$2200 \mathrm{ug} / \mathrm{ml}$} & Before & 0.0 & 12.0 & 8.0 & 0.0 & 6.0 & 24.0 & 0.0 & 10.0 \\
\hline & After & $\begin{array}{c}0.0 \\
(0.0)\end{array}$ & $\begin{array}{l}12.0 \\
(0.0)\end{array}$ & $\begin{array}{c}11.0 \\
(37.5)\end{array}$ & $\begin{array}{c}0.0 \\
(0.0)\end{array}$ & $\begin{array}{c}6.0 \\
(0.0)\end{array}$ & $\begin{array}{l}26.0 \\
(8.3)\end{array}$ & $\begin{array}{c}0.0 \\
(0.0)\end{array}$ & $\begin{array}{c}16.0 \\
(16.0)\end{array}$ \\
\hline \multirow[b]{2}{*}{$2240 \mathrm{ug} / \mathrm{ml}$} & Before & 0.0 & 12.0 & 8.0 & 0.0 & 6.0 & 24.0 & 0.0 & 10.0 \\
\hline & After & $\begin{array}{c}0.0 \\
(0.0)\end{array}$ & $\begin{array}{c}18.0 \\
(50.0)\end{array}$ & $\begin{array}{c}16.0 \\
(50.0)\end{array}$ & $\begin{array}{c}0.0 \\
(0.0)\end{array}$ & $\begin{array}{c}9.0 \\
(50.0)\end{array}$ & $\begin{array}{c}38.0 \\
(58.1)\end{array}$ & $\begin{array}{c}0.0 \\
(0.0)\end{array}$ & $\begin{array}{c}17.0 \\
(70.0)\end{array}$ \\
\hline
\end{tabular}

Table 2 shows the sensitivity profile of $\mathrm{EC}_{2}$ (Escherichia coli strain 2) after treatment with thioridaxine dilutions. The 
uropathogen was resistant to nalidixic acid, cefuroxime, tetracycline and augmentin. The uropathogen $\mathrm{EC}_{2}$ was sensitive to gentamicin, ciprofloxacin, chloramphenicol, ofloxacin and nitrofurantoin with $12.0 \mathrm{~mm}, 8.0 \mathrm{~mm}, 6.0 \mathrm{~mm}$, $24.0 \mathrm{~mm}$ and $10.0 \mathrm{~mm}$ zones of inhibition respectively (Table 1). Table 2 also shows data of zones of inhibition of E.coli strains 2 after treatment with laboratory dilutions of thioridaxine. Zones of inhibition before and after treatment were also mathematically computed to obtain $\leq 50.0 \%$ loss in resistance (i.e. improvement in sensitivity). Treatment with $2000 \mathrm{ug} / \mathrm{ml}$ thioridaxine recorded a $115 \%$ loss of resistance to chloramphenicol, $90.0 \%$ loss in resistance to nitrofurantoin, less than $20 \%$ and $30 \%$ resistance losses to gentamicin and ciprofloxacin respectively,

Sensitivity improvement or resistance loss as high as $250.0 \%$ was recorded for ciprofloxacin after treatment with $2040 \mathrm{ug} / \mathrm{ml}$ dilution of the chemical agent. Gentamicin was distantly next with a less than $40.0 \%$ loss of resistance. After $2080 \mathrm{ug} / \mathrm{ml}$ thioridaxine treatment, $50 \%$ resistance loss was recorded for gentamicin, ciprofloxacin, chloramphenicol and nitrofurantoin each. The same curing treatment resulted in a less than $15 \%$ resistance loss to ofloxacin. Seventy five percent $(75 \%), 50 \%$ and $80 \%$ resistance losses were recorded for ciprofloxacin, ofloxacin and nitrofurantoin respectively after the uropathogen was treated with $2120 \mathrm{ug} / \mathrm{ml}$ dilution of thioridaxine. Whereas $112.5 \%$ loss of resistance was recorded for ciprofloxacin, $100 \%$ and $130 \%$ losses were recorded for chloramphenicol and nitrofurantoin respectively after $2160 \mathrm{ug} / \mathrm{ml}$ thioridaxine treatment. After $2200 \mathrm{ug} / \mathrm{ml}$ treatment, $60 \%$ loss of resistance was recorded for nitrofurantoin while less than $40 \%$ and $10 \%$ losses were recorded for ciprofloxacin and ofloxacin respectively. Fifty percent $(50 \%), 50 \%, 50 \%, 58.1 \%$ and $70 \%$ resistance losses were recorded for gentamicin, ciprofloxacin, chloramphenicol, ofloxacin and nitrofurantoin respectively after $2240 \mathrm{ug} / \mathrm{ml}$ thioridaxine treatment.

Table 3 is a summary of $\leq 50 \%$ loss of antibiotic resistance after $2000-2240 \mathrm{ug} / \mathrm{ml}$ treatment with thioridaxine laboratory dilutions. With regard to Table1, only gentamicin, ciprofloxacin, chloramphenicol, ofloxacin and nitrofurantoin recorded $\leq 50 \%$ loss in resistance. Thioridaxine dilutions of $2040 \mathrm{ug} / \mathrm{ml}, 2160 \mathrm{ug} / \mathrm{ml}$ and $2240 \mathrm{ug} / \mathrm{ml}$ recorded mean \pm S.E loss of resistance for all five antibiotics of $68.0 \pm 16.3 \%$ and $55.0 \pm 25.0 \%$ respectively. Less than $45 \%, 45 \%, 45 \%$ and $15 \%$ loss of resistance were effected by 2000, 2080, 2120 and $2200 \mathrm{ug} / \mathrm{ml}$ laboratory dilutions of thioridaxine for all five antibiotics. All the dilutions put together recorded mean \pm S.E loss of resistance of $76.8 \pm 23.1 \%$ and $81.4 \pm 19.6 \%$ for ciprofloxacin and nitrofurantoin respectively. Also, the combined effect of all seven laboratory dilutions of thioridaxine recorded less than $15 \%, 16 \%$ and $50 \%$ loss of resistance for gentamicin, ofloxacin and chloramphenicol respectively.

Table 3. Summary of $\leq 50 \%$ loss of resistance as induced by thioridaxine dilutions treatment on MDR Escherichia coli uropathogen

\begin{tabular}{lllllll}
\hline \multirow{2}{*}{$\begin{array}{l}\text { Thioridaxine } \\
\text { dilutions }\end{array}$} & \multicolumn{6}{c}{ Antibiotics whose Resistance was reduced by $\leq \mathbf{5 0 . 0} \%$} \\
\cline { 2 - 7 } & $\begin{array}{l}\text { GEN } \\
(\%)\end{array}$ & $\begin{array}{l}\text { CPR } \\
(\%)\end{array}$ & $\begin{array}{l}\text { OFL } \\
(\%)\end{array}$ & $\begin{array}{l}\text { NIT } \\
(\%)\end{array}$ & $\begin{array}{l}\text { CHL } \\
(\%)\end{array}$ & mean \pm S.E \\
\hline $2000 \mathrm{ug} / \mathrm{ml}$ & 0.0 & 0.0 & 0.0 & 90.0 & 115.0 & $41.0 \pm 24.4$ \\
$2040 \mathrm{ug} / \mathrm{ml}$ & 0.0 & 250.0 & 0.0 & 50.0 & 50.0 & $68.0 \pm 24.4$ \\
$2080 \mathrm{ug} / \mathrm{ml}$ & 50.0 & 50.0 & 0.0 & 50.0 & 50.0 & $40.0 \pm 11.8$ \\
$2120 \mathrm{ug} / \mathrm{ml}$ & 0.0 & 75.0 & 50.0 & 80.0 & 0.0 & $41.0 \pm 13.2$ \\
$2160 \mathrm{ug} / \mathrm{ml}$ & 0.0 & 112.5 & 0.0 & 130.0 & 100.0 & $68.5 \pm 16,3$ \\
$2200 \mathrm{ug} / \mathrm{ml}$ & 0.0 & 0.0 & 0.0 & 6.0 & 0.0 & $12.0 \pm 5.7$ \\
$2240 \mathrm{ug} / \mathrm{ml}$ & 50.0 & 50.0 & 58.1 & 70.0 & 50.0 & $55.6 \pm 25.0$ \\
\hline
\end{tabular}

Data on the effect of thioridaxine dilutions on the minimum inhibitory concentration (MIC) of chloramphenicol on the multidrug resistant Escherichia coli uropathogen are shown in Table 4. At the end of 24 hours incubation at $37^{\circ} \mathrm{C}$ of the experimental set up, inoculum control tubes for all thioridaxine dilutions (2000-2240ug/ml) showed turbidity (cloudiness) as expected. As expected also, sterile broth control and drug control tubes remained clear at the end of incubation. Laboratory dilutions of $2000 \mathrm{ug} / \mathrm{ml}, 2040 \mathrm{ug} / \mathrm{ml}$, $2120 \mathrm{ug} / \mathrm{ml}$ and $2200 \mathrm{ug} / \mathrm{ml}$ did not affect the minimum inhibitory concentration (MIC) of chloramphenicol as the MIC remained 30ug. Reductions in MIC of chloramphenicol were however effected by $2080 \mathrm{ug} / \mathrm{ml}, 2160 \mathrm{mg} / \mathrm{ml}$ and $2240 \mathrm{ug} / \mathrm{ml}$ thioridaxine dilutions. Thioridaxine dilutions of $2080 \mathrm{ug} / \mathrm{ml}$ and $2160 \mathrm{ug} / \mathrm{ml}$ reduced chloramphenicol MIC to $15 \mathrm{ug}$ each which is a two-fold reduction, while $2240 \mathrm{ug} / \mathrm{ml}$ reduced the MIC to 7.5ug (a four-fold reduction).

Table 4. The effect of thioridaxine dilutions on the minimum inhibitory concentration (MIC) of chloramphenicol on a multidrug resistant Escherichia coli isolate obtained from mid-stream urine after $24 \mathrm{hr}$ incubation at $370 \mathrm{C}$

\begin{tabular}{|c|c|c|c|c|c|c|c|c|c|c|c|}
\hline \multirow{2}{*}{$\begin{array}{l}\text { Thioridaxine } \\
\text { Dilutions (ug/ml) }\end{array}$} & \multirow{2}{*}{$\begin{array}{l}\text { New MIC after } \\
\text { Thioridaxine } \\
\text { Treatment }\end{array}$} & \multicolumn{10}{|c|}{ Serial dilutions of chloramphenicol (ug) } \\
\hline & & 120.0 & 60.0 & 30.0 & 15.0 & 7.50 & 3.75 & 1.88 & $\begin{array}{c}\text { Inoculum } \\
\text { control }\end{array}$ & $\begin{array}{c}\text { Sterile } \\
\text { Broth control } \\
\end{array}$ & $\begin{array}{c}\text { Drug } \\
\text { control }\end{array}$ \\
\hline 2000 & No change & - & - & - & + & + & + & + & + & - & - \\
\hline 2040 & No change & - & - & - & + & + & + & + & + & - & - \\
\hline 2080 & 15 ug(2-fold) & - & - & - & - & + & + & + & + & - & - \\
\hline 2120 & No change & - & - & - & + & + & + & + & + & - & - \\
\hline 2160 & 15ug(2-fold) & - & - & - & - & + & + & + & + & - & - \\
\hline 2200 & No change & - & - & - & + & + & + & + & + & - & - \\
\hline 2240 & 7.5ug(4-fold) & - & - & - & - & - & + & + & + & - & - \\
\hline
\end{tabular}




\section{Discussion}

This study has the underlining intent of making suggestions aimed at reclaiming some common old and not too old drugs which are losing therapeutic usefulness owing to ineffectiveness in terms of therapeutic outcome. The alternative is to replace the old drugs with new ones but it will be counter-productive because such new drugs may be more costly, may be toxic (i.e. may have more adverse side effects), their use may need much longer stay in the hospital (or longer duration of treatment) and their use may require treatment in intensive care units.

Antibiotic susceptibility profiles of all five strains (uropathogens) of Escherichia coli before thioridaxine treatment in this study showed that the five uropathogen strains were sensitive to gentamicin, ciprofloxacin, chloramphenicol, ofloxacin and nitrofurantoin with mean \pm SE zones of inhibition of $10.6 \pm 7.2 \mathrm{~mm}, 10.2 \pm 8.8 \mathrm{~mm}, 8.2$ $\pm 5.6 \mathrm{~mm}, 15.6 \pm 20.1 \mathrm{~mm}$ and $9.6 \pm 11.3 \mathrm{~mm}$ respectively. The implication of this is that $5(55.6 \%)$ of the antibiotics recorded positive reactions at the end of incubation. Whereas the five uropathogen strains were resistant to augmentin, strain $\mathrm{EC}_{2}$ resisted cefuroxime, nalidixic acid and tetracycline. Strains $\mathrm{EC}_{1}$ and $\mathrm{EC}_{4}$ resisted cefuroxime also. The fact that $\mathrm{EC}_{2}$ strain resisted three antibiotics qualifies it as a multidrug organism (Jan et al., 2004; Otajevwo, 2012). Findings suggest that infections or diseases caused by MDR Escherichia coli strain 2 in the study environment and perhaps in other environments can be treated successfully with gentamicin/ciprofloxacin/ofloxacin (i.e. any one of the three) only or in synergistic combination with either chloramphenicol or nitrofurantoin or any other combination a physician may consider safe and potent. The privilege of choosing any of chloramphenicol, gentamicin or nitrofurantoin as alternative to ciprofloxacin or ofloxacin (both fluoroquinolones) will be cheering to low income patients in terms of availability. The total resistance recorded against augmentin is worrisome because it is a drug that is used to treat a good number of human diseases. Some authors have also expressed similar worry over augmentin in terms of antibiotic susceptibility (Oluremi et al., 2011; Otajevwo, 2012; Otajevwo, 2014). It was not clear as to whether the site from where the pathogens were isolated had any direct or indirect effect on the antibiograms of the strains as recorded in this study. However, it may be possible that $\mathrm{pH}$ changes or variation from site and presence /absence of oxygen could affect the response of Escherichia coli (a facultative aerobe) to relevant antibiotics it is exposed to invitro. The sensitivity profile obtained in this study however, is subject to verification and confirmation by other researchers.

The fact that each of the five strains was resistant to onethree of the antibiotics used in this study may suggest that very large population of Escherichia coli organisms have been exposed to several antibiotics (Oluremi et al., 2011). Thioridaxine laboratory dilutions of $2000 \mathrm{ug} / \mathrm{ml}, 2040 \mathrm{ug} / \mathrm{ml}$, $2080 \mathrm{ug} / \mathrm{ml}, \quad 2120 \mathrm{ug} / \mathrm{ml}, \quad 2160 \mathrm{ug} / \mathrm{ml}, \quad 2200 \mathrm{ug} / \mathrm{ml}$ and
$2240 \mathrm{ug} / \mathrm{ml}$ were used to treat and cure five uropathogenic strains of Escherichia coli with the intent of reducing their resistance significantly or eliminating it completely. The loss of $50-100 \%(\leq 50 \%)$ of resistance after treatment with the stated dilutions of thioridaxine was used as the basis of establishing the curing effects of these dilutions. The use of $50 \%$ and above loss in resistance as a criterion to determine the extent of plasmid curing was according to the scheme provided by Akortha et al. (2011). Stanier et al. (1984) reported that the elimination of plasmids by dyes and other natural agents reflects the ability of such an agent to inhibit plasmid replication at a concentration that does not affect the chromosome.

After treatment with 2000-2240ug/ml thioridaxine dilutions, Escherichia coli strain 2 still remained completely resistant to nalidixic acid, cefuroxime, tetracycline and augmentin. This could be due to the fact that plasmids responsible for resistance to these drugs (present in the genome of the uropathogen) may be chromosome- mediated or non- conjugative plasmids (Akortha and Filgona, 2009). Each of the seven laboratory dilutions induced $\leq 50.0 \%$ loss of resistance of the uropathogen to nitrofurantoin (Table 2). Thioridaxine dilution of $2000 \mathrm{ug} / \mathrm{ml}$ induced $115 \%$ and $90 \%$ loss of resistance of the uropathogen to chloramphenicol and nitrofurantoin respectively. This represented $2(22.2 \%)$ of the total selected drugs used in this study. Also, only two antibiotics namely ciprofloxacin and nitrofurantoin recorded $250 \%$ and $90 \%$ resistance losses respectively after $2040 \mathrm{ug} / \mathrm{ml}$ thioridaxine treatment. In a similar study, some authors have used $2000 \mathrm{ug} / \mathrm{ml}$ thioridaxine dilution treatment to induce loss of resistance (enhance antibiotic sensitivity) in some multidrug resistant strains of Pseudomonas aeruginosa and recorded elimination (curing) of antibiotic resistance in thioridaxine treated strains (Mukherjee et al., 2012). It was concluded in their report that the antipsychotic drugthioridaxine is a potent agent able to eliminate drug resistance plasmids which are much longer in size than the plasmids of other gram negative bacteria (Mukherjee et al., 2012). Thioridaxine dilution of $2080 \mathrm{ug} / \mathrm{ml}$ induced $\leq 50 \%$ resistance loss to gentamicin, ciprofloxacin, chloramphenicol and nitrofurantoin. Whereas mean \pm S.E percentage loss of resistance after $2040 \mathrm{ug} / \mathrm{ml}$ treatment of the uropathogen was $68.0 \pm 24.4 \%, 2080 \mathrm{ug} / \mathrm{ml}$ thioridaxine treatment recorded $40.0 \pm 11.8$ (less than 50\%) loss of resistance (Table 3). Resistance losses of $75 \%, 50 \%$ and $80 \%$ for ciprofloxacin, ofloxacin and nitrofurantoin respectively were recorded after $2120 \mathrm{ug} / \mathrm{ml}$ thioridaxine treatment with a corresponding mean \pm S.E resistance loss of $41.0 \pm 13.2 \%$ (which is less than $50 \%$ ). Laboratory thioridaxine dilutions of $2160 \mathrm{ug} / \mathrm{ml}$ and $2240 \mathrm{ug} / \mathrm{ml}$ effected $112.5 \%, 100 \%$ and $130 \%$ resistance losses for ciprofloxacin, chloramphenicol and nitrofurantoin respectively for the first dilution and 50\%, 50\%, 50\%, 58.1\% and $70 \%$ resistance losses for gentamicin, ciprofloxacin, chloramphenicol, ofloxacin and nitrofurantoin respectively for the second dilution. Both dilutions however, recorded corresponding mean \pm S.E resistance losses of $68.5 \pm 16.3 \%$ 
and $55.6 \pm 25.0 \%$ respectively.

The lowest resistance loss was recorded by $2200 \mathrm{ug} / \mathrm{ml}$ which recorded more than $50 \%$ resistance loss for nitrofurantoin only with a corresponding $12.0 \pm 5.7 \%$. From these results, it seems any of thioridaxine dilutions of $2160 \mathrm{ug} / \mathrm{ml}$ or $2040 \mathrm{ug} / \mathrm{ml}$ or $2240 \mathrm{ug} / \mathrm{ml}$ may possess the capacity to eliminate resistance put up by multidrug resistant strains of E.coli and therefore, could be administered in the therapeutic control of various infections caused by such bacteria. According to Mukherjee et al. (2012), the simultaneous application of thioridaxine to patients may open up a new arena of therapy. The simultaneous application of thioridaxine may not only act as an additional antibacterial agent but may also help to eliminate the drug resistant plasmids from the infectious bacterial cells (Spendler et al., 2006). Hence patients suffering from MDR Escherichia coli infections may be administered thioridaxine at standard human doses (using $2160 \mathrm{ug} / \mathrm{ml}$ or $2040 \mathrm{ug} / \mathrm{ml}$ or $2240 \mathrm{ug} / \mathrm{ml}$ as a basis) along with antibiotics especially gentamicin, chloramphenicol, nitrofurantoin or any of the fluoroquinolones (ciprofloxacin, ofloxacin).

Also in this study, sensitivity enhancement effect of thioridaxine laboratory dilutions on the minimum inhibitory concentration (MIC) of chloramphenicol as it affected MDR E.coli strain 2 uropathogen showed a two-fold (15ug), twofold (15ug) and four fold (7.5ug) reductions in MIC of chloramphenicol as recorded for $2080 \mathrm{ug} / \mathrm{ml}, 2160 \mathrm{ug} / \mathrm{ml}$ and $2240 \mathrm{ug} / \mathrm{ml}$ thioridaxine dilutions respectively. Some authors had reported similar findings on MDR Staphylococcus aureus strains (Otajevwo and Momoh, 2013) as well as on MDR strains of Pseudomonas aeruginosa using acridine orange (Otajevwo and Okungbowa, 2014). Otajevwo (2012) reported similar results using ethidium bromide dilutions on MDR strain of E.coli. A fast and accurate determination of MIC can ensure optimal effective treatment of patients while at the same time avoiding over-prescription. This will save money for healthcare providers as well as reduce development of resistance (NCCLS, 2000; McGowan and Wise, 2001).

The MIC of chloramphenicol which is 30ug (based on long standing research) was reduced to $15 \mathrm{ug}$ (two fold reduction), 15ug (two fold reduction) and 7.5ug (four fold reduction) by thioridaxine laboratory dilutions of $2080 \mathrm{ug} / \mathrm{ml}$, $2160 \mathrm{ug} / \mathrm{ml}$ and $2240 \mathrm{ug} / \mathrm{ml}$ respectively as tested on multiple resistant drug strain of Escherichia coli isolated from the urinary tract of a patient. According to Dimitru et al. (2006), there is a significant correlation between MIC values and the inhibition zone diameters obtained by a $30 \mathrm{ug}$ disc. The lower the MIC and the larger the zone of inhibition, the more susceptible the microorganism is to the antimicrobial agent and conversely, the higher the MIC and smaller the zone of inhibition, the more resistant the microorganism (Dimitru et al., 2006).

The medical implication therefore of the two-fold, twofold and four-fold reduction of chloramphenicol MIC by thioridaxine dilutions of $2080 \mathrm{ug} / \mathrm{ml}, 2160 \mathrm{ug} / \mathrm{ml}$ and $2240 \mathrm{ug} / \mathrm{ml}$ respectively is that when doses of one of these dilutions or a combination of any two are incorporated into the manufacture of chloramphenicol or any other related antibiotic and then administered to a patient diagnosed to be suffering from a disease caused by MDR E.coli strain, a better result in terms of outcome (cure of the disease) may be achieved as it will require four times its concentration to function invivo. In a related work, Kohler (2010) showed that the resistance of $P$. aeruginosa to tetracycline efflux was reduced from MIC 0.032 to $0.004 \mathrm{ug} / \mathrm{ml}$ (an eight- fold reduction) by treatment with phenothiazine. Crowle et al. (1992) demonstrated that non- toxic concentrations of phenothiazine in the lungs achieved complete elimination of Mycobacterium tubercolosis. In a related study, some workers had reported the capacity of an aqueous methanolic plant- extract- epidiosbulbin- E- Acetate (EEA) to decrease the MIC of antibiotics against MDR bacteria thus making antibiotic treatment more effective (Shiram et al., 2008)

\section{Conclusion}

Thioridaxine laboratory dilutions of $2040 \mathrm{ug} / \mathrm{ml}$, $2160 \mathrm{ug} / \mathrm{ml}$ and $2240 \mathrm{ug} / \mathrm{ml}$ induced more than $50 \%$ resistance losses for gentamicin, ciprofloxacin, ofloxacin, nitrofurantoin and chloramphenicol. Also, 2080ug/ml, 2160ug/ml and $2240 \mathrm{ug} / \mathrm{ml}$ thioridaxine dilutions effected chloramphenicol MIC reductions by two-fold, two-fold and four-fold respectively. Hence, patients suffering from MDR Escherichia coli infections may be administered thioridaxine at standard human doses (using $2160 \mathrm{ug} / \mathrm{ml}$ and or $2240 \mathrm{ug} / \mathrm{ml}$ as a basis) along with any of the above antibiotics (singly or in combination). It is hoped that this simultaneous or part application of thioridaxine with antibiotics will eliminate plasmids while enhancing the penetration of antibiotics into pathogenic bacterial cells especially those of MDR E.coli. The overall effect of this is that patient recovery will be facilitated and hospital stay and hospital cost would be drastically reduced.

\section{Suggestions for Further Studies}

The determination of resistance loss by multidrug resistant E.coli strain 2 after treatment with $2080 \mathrm{ug} / \mathrm{ml}, 2160 \mathrm{ug} / \mathrm{ml}$ and $2240 \mathrm{ug} / \mathrm{ml}$ thioridaxine dilutions may not be totally convincing. It is recommended therefore, that the effects of these dilutions in the pathogen and indeed, other commonly known pathogens at the molecular level be probed further by carrying out plasmid profiling before and after treatment to see at what dilution(s) there is partial or total elimination of drug resistance " $\mathrm{R}$ " plasmid bands.

\section{References}

[1] Akhorta, E.E, Aluyi, H.A.S, Enerijiofi, K.E. (2011). Transfer of amoxicillin resistance gene among bacteria isolates from sputum of pneumonia patients attending the University of Benin Teaching Hospital, Benin City, Nigeria. J.Med.Med.Sci.2 (7):1003-1009. 
[2] Akortha, E.E and Filgona, J. (2009). Transfer of gentamicin resistance genes among enterobacteriaceae isolated from the outpatients with urinary tract infections attending 3 hospitals in Mubi, Adamawa State. Scientific Research and essay. 4(8): 745-752.

[3] Amara, L., Spendler, G., Martins, A and Molnar, J. (2013). Efflux pumps that bestow multidrug resistance of pathogenic gram negative bacteria. Biochem. Pharmacol. Journ. 2(3): 119-121.

[4] Barth, V.N., Charnet, E., Martin, L.J and Need, A.B. (2006). Comparison of rat dopamine D2 receptor occupancy for a series of anti-psychotic drugs like thioridaxine. Life Science. 78(26): 3007-3019.

[5] Bauer, A.W, Kirby, W.M.M, Sherris, J.C, Turk, M. (1966). Antibiotic susceptibility testing by a standardized single disc method. Am.J.Clin.Pathol. 45:493-496.

[6] Bergeron, M.G. (1995). Treatment of pyelonephritis in adults. Med. Clin. N. Am. 75: 619 - 649.

[7] Byron, F, Brehm, S, Eric, A.J. (2003). Sensitization of Staphylococcus aureus and Escherichia coli to antibiotics by these sesquiterpenoids. Antimicrob. Agents Chemother. 47(10):3357-3360.

[8] Chakrabarthy, P.K., Mishra, A.K and Chakrabarti, S.K. (1984). Loss of plasmid-like drug resistance after treatment with iododeoxyuridine. Indian Journ. Expt. Biol. 22: 333-334.

[9] Cowan, S.T and Steel, K.J. (1993). Manual for the identification of medical bacteria. 3rd edn. Cambridge University Press. Lonon, New York, Rockville, Melbourne and Sydney. 150p.

[10] Crowle, A.J, Douvas, S.G, May, M.H. (1992). Chlorpromazine: a drug potentially useful for treating Mycobacterial infections. Chemotherapy. 38:410-419.

[11] Dimitru, G., Poiata, A., Tuchilus, C and Buiuc, D. (2006). Correlation between linezolid zone diameter and minimum inhibitory concentration valves determined by regression analysis. Rev. Med. Chir. Soc. 110(4): 1016-1025.

[12] Gupta, T.D., Bandyopathy, T., Dastidar, S.G., Bandopadhyay, M., Mistra, A and Chakrabarty, A.N. (1980). R- plasmids of Staphylococci and their elimination by different agents. Indian Journ. Expt. Biol. 18: 478-481.

[13] Jan, M.B, John, D.T, Sentry, P. (2002). High prevalence of oxacillin resistant Staph aureus isolates from hospitalized patients in Asia-Pacific and South Africa: Results from SENTRY antimicrobial surveillance program. 1998-1999. Antimicrob. Agent Chemother. 46: 879-881.

[14] Johnson, J., Kuskowski, M., Menard, M., Gajewski, A., Xercavins, M and Garau, J. (2006). Similarity between human and chicken

[15] Escherichia coli isolates in relation to ciprofloxacin resistance status. Journ. Infect. Dis. 194(1): 71-78.

[16] Kohler, N.O. (2010). Non- antibiotics Reverse Resistance of Bacteria to Antibioticsin vivo. J.Antimicrob.Chemother. 24(5):751-754.

[17] Madigan, M., Martinko, J and Parker, J. (2003). Brock Biology of Microorganisms (10th edn). Prentice Hall, Upper Saddle River, NJ., USA. 500p.
[18] Mbata TI (2007). Prevalence and antibiogram of UTI among prisons Inmates in Nigeria. Inter. Journ. Microbiol. 3(2):10-15.

[19] McGowan, J.E. (2006). Resistance in non-fermenting gram negative bacteria: multidrug resistance to the maximum. American Journ. Infect. Control. 34: 29-37.

[20] McGowan, A.P and Wise, R. (2001). Establishing MIC breakpoints and the interpretation of invitro susceptibility tests. Journ. Antimicrob. Chemother. 48: 17-28.

[21] Mukherjee, S, Chaki, S, Das, S, Sen, S, Datta, S.K, Dastidar, S.G. (2011). Distinct synergistic action of piperacillin and methylglyoxal against Pseudomonas aeruginosa. Indian $\mathrm{J}$. Exp.Biol. 49: 447-551.

[22] Mukherjee, S., Chaki, S., Barman, S., Das, H., Koley and Dastidar, S.G. (2012). Effective elimination of drug resistance genes in pathogenic Pseudomonas aeruginosa by an antipsychotic agent-thioridaxine. Current Research in Bacteriology. 5:36-41.

[23] Namita, J., Pushpa, S and Lalit, S. (2012). Control of multidrug resistant bacteria in a tertiary care hospital in India. Antimicrob. Resistance \& Infection Control. 1: 23-30.

[24] NCCLS. (2000). Methods for dilution, Antimicrobial Susceptibility Tests for bacteria that grow aerobically. Approved Standard (5th edition). Wayne, PA, USA.

[25] Neu, H.C. (1989). Overview of mechanisms of bacterial resistance. Diagnost. Microbiol. Infect. Dis. 12: 109-116.

[26] Obaseki-Ebor, E.E. (1984). Rifampicin curing of plasmids in Escherichia coli K12 rifampicin resistant host. Journ. Pharm. Pharmacol. 36: 467-470.

[27] Ochei, J and Kolhhatkar, A. (2008). Medical Laboratory: Theory and practice, 10the edition. New Delhi: Tata McGrawHill Publishing Company. 1338p.

[28] Okeke, I.N., Lamikanra, A and Edelman, R. (1999). Socioeconomic and behavioural factors leading to acquired bacterial resistance to antibiotics in developing countries. Emerging Infectious Diseases. 5: 18-27.

[29] Oluremi, B.B, Idowu, A.O, Olaniyi, J.F. (2011). Antibiotic susceptibility of common bacterial pathogens in urinary tract infections in a Teaching Hospital in Southwestern Nigeria. Afr. J. Microbiol. Res. 5(22): 3658-3663.

[30] Oskay, M., Oskay, D and Kalyoneu, F. (2009). Activity of some plant extracts against multidrug resistant human pathogens. Iranian Journ. Pharm. Research. 8(4): 293-300.

[31] Otajevwo, F.D. (2012). Sensitivity Enhancement of Multidrug Resistant Urinary Tract Escherichia coli isolate to some commonly used Antibiotics after treatment with Non-Toxic Laboratory Concentrations of Homodium Bromide. IOSR J. Pharm. 2(3): 540-568

[32] Otajevwo, F.D and Momoh, S.A. (2013). Resistance marker loss of multi-drug resistant (MDR) Staphylococcus aureus strains after treatment with dilutions of acridine orange. Journ. Med. \& Med. Sci. 2(2):43-62. ISSN: 2241-2328.

[33] Otajevwo, F.D and Okungbowa, A. (2014). A study on resistance loss of multidrug resistant (MDR) Pseudomonas aeruginosa strains after treatment with dilutions of acrdine orange. International Journal of Medicine \& Medical Sciences. 6(1): 24-33. 
[34] Paterson, D.L and Bonomo, R. A. (2005). Extended spectrum beta-lactamase: a clinical update. Clin. Microbiol. Rev. 18(4): 657-686. DOI. 101.1128/CMR.18.4.

[35] Reddy, G., Shridhar, P and Polasa, H. (1986). Elimination of Col. E1(pBR322 and pBR329) plasmids in Escherichia coli on treatment with hexamine ruthenium chloride. Curr. Microbiol. $13: 243-246$.

[36] Salyers, A.A and Amabile-Cuevas, C.F. (1997). Why are antibiotic resistance genes so resistant to elimination? Ant. Ag. Chemo. 41(11): 2321-2325.

[37] Shiram, V., Jahagirdar, S., Latha, C., Kumar, V., Puranik, V., Rojatkar, S. (2008). A potential plasmid curing agent, 8epidiosbulbin E acetate

[38] from Dioscorea bulbifera L against multidrug resistant bacteria. Int. Journ. Antimicrob. Agents. 32(5): 405-410.

[39] Stainer, R.Y, Adelberg, E.A and Ingraham, J.L. (1984). General Microbiology, 4th edn.The Macmillan Press Ltd, Basingstoke London.
[40] Todar, K. (2007). Pathogenic Escherichia coli in online Textbook of Bacteriology. University of Wisconsin-Madison Press. 30p

[41] Trevors, J.T. (1986). Plasmid curing in bacteria. FEMS Microbiol. Rev. 32(3): 149-157.

[42] Viveiros, M., Jesus, A., Brito, M., Leandro, C and Martins, M. (2010). Inducement and reversal of tetracycline resistance in Escherichia coli $\mathrm{K} 12$ and expression of proton gradientdependent multidrug efflux pumps genes. Antimicrob. Agents Chemother. 49: 3578-3582.

[43] World Health Organization. (2012). Antimicrobial resistance in the European Union and the World. Lecture delivered by Dr Margaret Chan, Director-General of W.H.O at the Conference oncombating antimicrobial resistance: time for action. Copenhagen, Denmark, March 14th, 2012. 